\title{
Assessment of the haematological indices of albino rats fed diets supplemented with jackfruit bulb, seed or a blend of bulb and seed
}

\author{
Margaret Akpana AGIANG ${ }^{1 *}$, Bright Sunday DONGO ${ }^{1}$, Ima Okon WILLIAMS ${ }^{1}$ and \\ Ashang Bonny UTU-BAKU \\ ${ }^{I}$ Department of Biochemistry, University of Calabar, Calabar, Nigria. \\ ${ }^{2}$ Department of Biochemistry, Cross River University of Technology, Calabar, Nigeria. \\ *Corresponding author; E-mail: margaretagiang@yahoo.co.uk; Phone: +234(0)8066779635, \\ $+234(0) 8023904080$
}

\begin{abstract}
Haematological indices of albino rats fed diets supplemented with jackfruit seed (S), bulb (B) or seedbulb blend (SB) were assessed. Diets were compounded to include $10 \%, 30 \%$, and $50 \%$ of the seed (S10/90, S30/70, S50/50), bulb (B10/90, B30/70, B50/50), and seed-bulb blend (SB10/90, SB30/70, SB50/50). Sixty male albino rats, divided into 10 groups of six rats each, were used. Group 1 (control) was fed rat chow only; groups 2-10 were fed the experimental diets. After 28 days of feeding, the animals were sacrificed and whole blood collected for full blood counts. The results, compared to the control $(p<0.05)$, showed that supplementation exceeding S30/70 and B10/90 or SB10/90 showed significant $(\mathrm{p}<0.05)$ loss of body weight. Total WBC, lymphocyte and eosinophil counts were significantly $(\mathrm{p}<0.05)$ increased in the experimental groups. Hb was reduced in group B10/90 but RBC, Hb and PCV increased in B10/90 and SB10/90. The same trend was observed in MCV of groups B10/90 and B50/50. Platelet counts in the experimental groups were significantly similar to the control though lower in S30/70, B50/50 and SB50/50. Overall, data from this study suggest that diet supplementation with $10 \%$ jackfruit bulb or the seed-bulb blend is likely to provide some antianaemic benefits and enhance the immune system.
\end{abstract}

(C) 2017 International Formulae Group. All rights reserved.

Keywords: Haematology, jackfruit, bulb, seed, supplementation.

\section{INTRODUCTION}

Fruits are an important part of a healthy diet. They are generally low in calories, fat, sodium and cholesterol but high in micronutrients including provitamin A, vitamins $\mathrm{E}$ and $\mathrm{K}$, ascorbic acid, riboflavin, iron, iodine, calcium and other minerals (Dike and Nnamdi, 2012; Syahida et al., 2012) as well as antioxidants which are known to prevent oxidative damage of important biological compounds by reactive oxygen species (Shi et al., 2001; Agboola, 2014; Donfack et al., 2014). A number of studies have associated high fruit consumption with low risk of some life-threatening disorders like coronary heart disease (CHD), diabetes mellitus, obesity and cancer (Donaldson, 2004; Williams et al., 2009; Erasto and Tshikalange, 2010; Asif, 2014). Unfortunately, across the world, many fruits are lesser known, neglected and underutilized.

Jackfruit (Artocarpus heterophyllus) of the Moraceae family is one of such underutilized fruit species (Okafor et al., 2015). The fruit has been reported to be highly nutritious and beneficial to health (Morton, 
1987; Deepak, 2012; Kadir et al., 2014). According to Kevat (2013), the seeds are rich in vitamin $\mathrm{C}$ and other anti-oxidants which could help to boost the immune system (immunostimulative) and enhance the proper working of the white blood cells in the body; they also contain iron which helps to combat anaemia. The report of Morton (1987) on Jackfruit showed that it is capable of increasing glucose tolerance, implying that the fruit can be used to control blood glucose level. The enticing smell and luscious taste of jackfruit make it to be very popular among other fruits worldwide (Kristie, 2011). Thus, jackfruit is widely consumed for its organoleptic quality, nutritional roles and other health benefits.

Though a native of India, the jackfruit tree is widely cultivated and used for food throughout the tropical regions of the world (Ray, 2002). In Nigeria, jackfruit is one of the underutilized plant species; the ripe fruits are chewed raw to extract the juice while the seeds are often discarded (Okafor et al., 2015). In some parts of Cross River State, Nigeria, including Akamkpa Local Government Area (L.G.A), where the tree grows wildly, and jackfruit is used in the preparation of various traditional delicacies; the bulb is often eaten raw.

Haematological indices such as the number and morphology of erythrocytes, leucocytes, and thrombocytes are useful in disease diagnosis and monitoring (Oyewole et al., 2009; Owoeye et al., 2011; Celik et al., 2015). According to Etim et al. (2014), the examination of blood provides the opportunity to clinically investigate the nutritional, physiological and pathological status of an individual or an animal. The role of nutrition as a key modulator of blood haematology is increasingly being recognized. A number of studies have revealed that different diets could exert diverse effects on haematological indices of animals (Syahida et al., 2012; Erukainure et al., 2013; Balogun et al., 2014; Albokhadaim, 2015) and humans (Lavy, 1994; Haddad et al., 1999; Fernández et al., 2015). Okolo et al. (2015) in their study showed that $T$. occidentalis leaves, fermented or unfermented, potentially significantly regenerated haemoglobin in iron-deficient rats.

Most of the available nutrition reports on jackfruit have been on whole fruit with, possibly, none on its effect on blood function indices of the consumers. Jackfruit is composed of the pulp, seed and bulb but the commonly edible parts are the seeds and bulb. Nutritional and biochemical information on these edible parts will be of great benefit to the consumers in making the right food choices. Hence this study was carried out to determine the effect of feeding diets supplemented with jackfruit seed, bulb or a seed-bulb blend on the haematological indices of albino rats.

\section{MATERIALS AND METHODS Collection and identification of samples} Jackfruits were obtained from a village in Akamkpa L.G.A., Cross River State, Nigeria. The pod and plant parts were taken to the Department of Botany, University of Calabar, Calabar, Nigeria, where Mr Apejoye Frank Igbinohuo identified the plant and a voucher specimen (Voucher number: 117) was also deposited in the same Department for future reference.

\section{Treatment of samples}

The ripe pods were washed thoroughly under running tap water, cut open and the bulbs bearing the seeds were separated from the pulp. The seeds were further separated from the bulbs, and the seed coat peeled off. The seeds and bulbs were blended in an electric blender (Masters Chef Blender) to obtain test Samples 1 and 2 respectively. The blended samples were spread on stainless metal trays and dried in an air-circulating oven (Astell-Hearson) at $60{ }^{\circ} \mathrm{C}$ for $12 \mathrm{hr}$, then ground into powder. The seed powder was mixed homogenously with equal amount of the bulb powder to obtain Sample 3. The three samples were stored in a refrigerator at $4{ }^{\circ} \mathrm{C}$ prior to use.

\section{Animal study Animal feeding experiment}

A total of 60 male albino rats, weighing 80-140 $\mathrm{g}$, were purchased from the 
Animal House of the Department of Biochemistry, University of Calabar, Calabar, Nigeria. The rats were kept in clean cages in the Animal House of the Department and allowed one week for acclimatization before the commencement of the feeding experiment. Of the 60 rats, 6 rats constituted group 1 (control) and was fed normal rat chow; the remainder 54 were divided into 3 groups of 18 rats, with each further divided into 3 subgroups of 6 rats each. The 3 major groups were treated with diets supplemented with jackfruit seed (at 10\%, 30\% and 50\%), jack fruit bulb (at 10\%, 30\% and 50\%) and the seed-bulb blend (at 10\%, 30\% and 50\%) (Table 1). The experimental feeding lasted for 28 days during which food intake and body weight changes were recorded. Food and water were given ad libitum.

Food intake and body weight changes were measured as follows:

Daily Food intake $=$ Food supplied to each rat - (leftover + spilled food)

Body weight change $=$ Final weight - initial weight of each rat
Collection of blood and tissue samples for analysis

After 28 days feeding period, the animals were sacrificed twelve hours after the last feeding according to the European Convention for Protection of Vertebrate animals and other scientific purposes guidelines ETS-123 (European Treaty Series No 123, 2005). Each rat was anaesthetized and immediately dissected and whole blood was collected through cardiac puncture into Ethylene di-amine tetra acetic acid (EDTA)treated sample tubes.

\section{Haematological analysis}

Complete Blood Count (CBC) was carried out using the automated method based on Wallace Coulter principle (1956) for the analysis of $\mathrm{WBC}, \mathrm{RBC}$, platelets and their differential counts (counter machine model: Siemes 1608).

\section{Statistical analysis}

Data obtained were expressed as the mean \pm SEM using analysis of variance (ANOVA) of statistical package for social sciences (SPSS) software version 17 with Least Significant Difference (LSD post hoc test). Differences were considered significant at $\mathrm{p}<0.05$.

Table 1: Experimental groups and diets.

\begin{tabular}{ll}
\hline Experimental group & Diet \\
\hline Control & Normal rat chow \\
S10/90 & $10 \%$ jackfruit seed powder and $90 \%$ rat chow \\
& \\
S30/70 & $30 \%$ jackfruit seed powder and $70 \%$ rat chow \\
S50/50 & $50 \%$ jackfruit seed powder and $50 \%$ rat chow \\
B10/90 & $10 \%$ jackfruit bulb powder and $90 \%$ rat chow \\
B30/70 & $30 \%$ jackfruit bulb powder and $70 \%$ rat chow \\
B50/50 & $50 \%$ jackfruit bulb powder and $50 \%$ rat chow \\
SB10/90 & $10 \%$ jackfruit seed/bulb powder and $90 \%$ rat chow \\
SB30/70 & $30 \%$ jackfruit seed/bulb powder and $70 \%$ rat chow \\
SB50/50 & $50 \%$ jackfruit seed/bulb powder and $50 \%$ rat chow
\end{tabular}




\section{RESULTS}

\section{Food intake and body weight changes}

Results of the daily food intake and body weight changes of rats fed the experimental diets for 28 days and the control group are shown in Tables 2-4. There was a gradual decrease $(p<0.05)$ in body weight change with increase in the percentage of supplementation of jackfruit seed in the diet leading to a negative decrease at $50 \%$ supplementation (Table 2). This is reflected in the significantly $(p<0.05)$ lower daily food intake by the experimental groups compared to the control though group S30/70 recorded a high daily food intake. Supplementation of the diet with $10 \%$ jackfruit bulb gave a comparative $(\mathrm{p}>0.05)$ weight change with the control but increase in supplementation showed negative weight changes (Table 3), though daily food intake was either comparative ( $>0.05, B 10 / 90)$ to or higher $(\mathrm{p}<0.05, \mathrm{~B} 50 / 50)$ than the control, except group B30/70 which had the lowest daily food intake. Table 4 shows a significantly similar body weight changes in all the groups fed diets supplemented with jackfruit seed-bulb blend compared with the control except group SB 50/50 which had the lowest daily food intake.

\section{Effect on complete blood counts}

Tables 5-8 summarize the results of the complete blood count of albino rats fed diets supplemented with jackfruit seed, bulb or seed-bulb blend. The values for WBC, lymphocytes, and eosinophils (Table 5) were significantly $(p<0.01)$ increased in all the groups compared to the control except in few cases where lymphocytes were not detected; eosinophils values were comparable $(\mathrm{p}>0.01)$ with the control (SB50/50, SB30/70, and $\mathrm{SB} 10 / 90)$. RBC, Hb, and PCV concentrations (Table 6) were significantly $(\mathrm{p}<0.05)$ high (except $\mathrm{Hb}$ in group $\mathrm{B} 10 / 90$ ) in groups B10/90 and SB10/90 compared to the control. The same trend was observed in MCV of group B10/90 which was similar to that of group B50/50 (Table 7). Group B50/50 also showed significantly higher values of RDWSD and RDW-CV. Rats on diets supplemented with a blend of the seed and bulb (SB), however, showed similarities or lower concentration of all the RBC absolute values tested. The same trend was seen in the results from the groups fed with diet supplemented with the jackfruit seed.

Table 8 shows the results for the analysis of platelet indices of rats fed experimental diets compared to the control group. The platelet counts in all the experimental groups were significantly $(\mathrm{p}>0.05)$ similar to the control $\left(829.67 \pm 22.86 \times 10^{3}\right.$ cell $\left./ \mu \mathrm{L}\right)$ except in $\mathrm{S} 30 / 70$, B50/50 and SB50/50 which had lower values. The same trend was observed in the values obtained for PDW and MPV in all the groups except group B10/90 which had a significantly low value. The results obtained for P-LCR also showed that only group B30/70 had a significantly low value while others were similar to the control.

Table 2: Body weights and daily food intake of control and rats fed jackfruit seed diet (g).

\begin{tabular}{lllll}
\hline $\begin{array}{l}\text { Experimental } \\
\text { groups }\end{array}$ & Initial body wt & Final body wt & Body wt change & Food intake \\
\hline Control & $121.55 \pm 5.92$ & $128.03 \pm 5.82$ & $6.48 \pm 0.36$ & $17.06 \pm 0.38$ \\
$\mathrm{~S} 10 / 90$ & $79.37 \pm 2.63^{*}$ & $84.65 \pm 2.76^{*}$ & $5.28 \pm 0.51$ & $15.43 \pm 0.28^{*}$ \\
$\mathrm{~S} 30 / 70$ & $126.30 \pm 4.47^{\mathrm{a}}$ & $128.95 \pm 4.80^{\mathrm{a}}$ & $2.65 \pm 1.46^{*}$ & $16.72 \pm 0.37^{\mathrm{a}}$ \\
$\mathrm{S} 50 / 50$ & $79.55 \pm 3.82^{*}, \mathrm{~b}$ & $77.40 \pm 5.18^{*, \mathrm{~b}}$ & $-2.15 \pm 1.55^{*, \mathrm{a}, \mathrm{b}}$ & $15.50 \pm 0.30^{*}, \mathrm{~b}$ \\
\hline
\end{tabular}

Values are expressed as mean $\pm \mathrm{SEM}, \mathrm{n}=6 ; *=$ significantly different from control at $\mathrm{p}<0.05$;

$\mathrm{a}=$ significantly different from $\mathrm{S} 10 / 90$ at $\mathrm{p}<0.05 ; \mathrm{b}=$ significantly different from $\mathrm{S} 30 / 70$ at $\mathrm{p}<0.05$. wt $=$ weight. 
Table 3: Body weights and daily food intake of control and rats fed jackfruit bulb diet (g).

\begin{tabular}{|c|c|c|c|c|}
\hline $\begin{array}{l}\text { Experimental } \\
\text { groups }\end{array}$ & $\begin{array}{l}\text { Initial body } \\
\text { wt }\end{array}$ & Final body wt & Body wt change & Food intake \\
\hline Control & $121.55 \pm 5.92$ & $128.03 \pm 5.82$ & $6.48 \pm 0.36$ & $17.06 \pm 0.38$ \\
\hline $\mathrm{B} 10 / 90$ & $130.77 \pm 6.53$ & $138.23 \pm 5.97$ & $7.47 \pm 4.79$ & $17.57 \pm 0.22$ \\
\hline B30/70 & $120.22 \pm 8.56$ & $118.07 \pm 7.50^{\mathrm{a}}$ & $-2.15 \pm 2.08^{*}, \mathrm{a}$ & $16.48 \pm 0.18^{\mathrm{a}}$ \\
\hline $\mathrm{B} 50 / 50$ & $119.55 \pm 6.24$ & $116.22 \pm 5.03^{\mathrm{a}}$ & $-3.33 \pm 2.08^{*}, \mathrm{a}$ & $17.95 \pm 0.19^{*}, \mathrm{~b}$ \\
\hline
\end{tabular}

Table 4: Body weights and daily food intake of control and rats fed a blend of jackfruit seed and bulb (g).

\begin{tabular}{lclll}
\hline $\begin{array}{l}\text { Experimental } \\
\text { groups }\end{array}$ & Initial body wt & Final body wt & Body wt change & Food intake \\
\hline Control & $121.55 \pm 5.92$ & $128.03 \pm 5.82$ & $6.48 \pm 0.36$ & $17.06 \pm 0.38$ \\
SB10/90 & $112.83 \pm 5.41$ & $118.83 \pm 4.42$ & $6.00 \pm 1.71$ & $16.04 \pm 0.39$ \\
SB30/70 & $120.12 \pm 6.70$ & $126.50 \pm 4.73$ & $6.86 \pm 2.55$ & $13.97 \pm 1.82^{*}$ \\
SB50/50 & $137.50 \pm 6.28^{\mathrm{a}}$ & $137.65 \pm 5.94^{\mathrm{a}}$ & $0.15 \pm 0.62^{*}, \mathrm{a}, \mathrm{b}$ & $16.66 \pm 0.41$ \\
\hline
\end{tabular}

Values are expressed as mean $\pm \mathrm{SEM}, \mathrm{n}=6 ; *=$ significantly different from control at $\mathrm{p}<0.05$;

$\mathrm{a}=$ significantly different from SB10/90 at $\mathrm{p}<0.05 ; \mathrm{b}=$ significantly different from $\mathrm{SB} 30 / 70$ at $\mathrm{p}<0.05$. wt $=$ weight.

Table 5: Differential white blood cell counts in the different experimental groups.

\begin{tabular}{lllll}
\hline Groups & $\begin{array}{l}\text { WBC } \\
\left(\mathbf{x 1 0}^{\mathbf{3}} \text { cell/ } \boldsymbol{\mu L} \mathbf{L}\right)\end{array}$ & $\begin{array}{l}\text { Lymphocytes } \\
\left(\mathbf{x 1 0}^{\mathbf{3}} \text { cell/ } / \boldsymbol{\mu L}\right)\end{array}$ & Lymphocytes $(\%)$ & $\begin{array}{l}\text { Eosinophils } \\
\left.\mathbf{( x 1 0}^{\mathbf{3}} \text { cell/ } / \boldsymbol{\mu L}\right)\end{array}$ \\
\hline Control & $6.67 \pm 0.38$ & $0.90 \pm 0.49$ & $8.12 \pm 4.25$ & $0.18 \pm 0.03$ \\
SB50/50 & $13.97 \pm 0.68^{\mathrm{a}}$ & $10.73 \pm 0.89^{\mathrm{a}, \mathrm{g}}$ & $73.95 \pm 3.48^{\mathrm{a}, \mathrm{g}}$ & $0.14 \pm 0.02^{\mathrm{r}}$ \\
$\mathrm{SB} 30 / 70$ & $11.75 \pm 0.99^{\mathrm{a}}$ & $8.42 \pm 1.65^{\mathrm{a}}$ & $76.92 \pm 5.73^{\mathrm{a}}$ & $0.19 \pm 0.03^{\mathrm{r}}$ \\
$\mathrm{SB} 10 / 90$ & $12.87 \pm 1.53^{\mathrm{a}}$ & $10.48 \pm 1.55^{\mathrm{a}, \mathrm{g}, \mathrm{h}}$ & $73.90 \pm 5.65^{\mathrm{a}, \mathrm{g}, \mathrm{h}}$ & $0.15 \pm 0.03^{\mathrm{r}}$ \\
\hline
\end{tabular}




\begin{tabular}{|c|c|c|c|c|}
\hline $\mathrm{B} 50 / 50$ & $10.68 \pm 0.68^{\mathrm{a}, \mathrm{d}}$ & $8.80 \pm 0.55^{\mathrm{a}, \mathrm{d}, \mathrm{f}}$ & $89.93 \pm 0.25^{\mathrm{a}, \mathrm{d}, \mathrm{f}}$ & $0.49 \pm 0.01^{\mathrm{a}, \mathrm{e}, \mathrm{x}, \mathrm{y}}$ \\
\hline B30/70 & $14.57 \pm 0.49^{\mathrm{a}, \mathrm{e}}$ & $12.70 \pm 0.89^{\mathrm{a}, \mathrm{g}}$ & $77.32 \pm 10.26^{\mathrm{a}, \mathrm{g}}$ & $0.39 \pm 0.03^{\mathrm{a}, \mathrm{e}, \mathrm{x}, \mathrm{y}}$ \\
\hline B10/90 & $16.92 \pm 0.69^{\mathrm{a}, \mathrm{d}, \mathrm{e}}$ & $12.80 \pm 0.56^{\mathrm{a}, \mathrm{g}}$ & $78.02 \pm 3.61^{\mathrm{a}, \mathrm{g}}$ & $0.27 \pm 0.01^{\mathrm{b}, \mathrm{x}, \mathrm{y}}$ \\
\hline $\mathrm{S} 50 / 50$ & $15.30 \pm 0.99^{\mathrm{a}, \mathrm{f}}$ & $10.52 \pm 0.26^{\mathrm{a}, \mathrm{h}, \mathrm{g}}$ & $75.98 \pm 2.33^{\mathrm{a}, \mathrm{h}, \mathrm{g}}$ & $0.23 \pm 0.02^{\mathrm{y}, \mathrm{r}, \mathrm{z}}$ \\
\hline $\mathrm{S} 30 / 70$ & $12.46 \pm 1.27^{\mathrm{a}}$ & $0.00 \pm 0.00$ & $0.00 \pm 0.00^{\mathrm{e}, \mathrm{i}}$ & $0.20 \pm 0.03^{r}$ \\
\hline $\mathrm{S} 10 / 90$ & $14.52 \pm 1.12^{\mathrm{a}, \mathrm{f}}$ & $9.26 \pm 1.68^{\mathrm{a}, \mathrm{h}, \mathrm{g}}$ & $74.19 \pm 3.47^{\mathrm{a}, \mathrm{h}, \mathrm{g}}$ & $0.18 \pm 0.03^{r}$ \\
\hline
\end{tabular}

Table 6: Concentrations of RBC, $\mathrm{Hb}$ and PCV in the different experimental groups.

\begin{tabular}{|c|c|c|c|}
\hline Groups & $\begin{array}{c}\text { RBC } \\
\left(\times 10^{6} \text { cell } / \mu \mathrm{L}\right)\end{array}$ & $\begin{array}{c}\text { Hb } \\
(\mathrm{g} / \mathrm{dL})\end{array}$ & $\begin{array}{l}\text { PCV } \\
(\%)\end{array}$ \\
\hline Control & $7.09 \pm 0.24$ & $14.00 \pm 0.14$ & $48.33 \pm 0.40$ \\
\hline $\mathrm{SB} 50 / 50$ & $6.46 \pm 0.09$ & $13.32 \pm 0.12$ & $45.23 \pm 0.35^{\mathrm{x}}$ \\
\hline $\mathrm{SB} 30 / 70$ & $7.02 \pm 0.31$ & $13.67 \pm 0.49$ & $47.59 \pm 1.17$ \\
\hline SB10/90 & $7.65 \pm 0.26^{\mathrm{d}}$ & $14.65 \pm 0.51$ & $52.32 \pm 1.47^{\mathrm{c}, \mathrm{e}}$ \\
\hline $\mathrm{B} 50 / 50$ & $6.30 \pm 0.29^{c}$ & $12.62 \pm 0.59^{f}$ & $44.05 \pm 2.57^{\mathrm{x}}$ \\
\hline B30/70 & $6.17 \pm 0.42^{\mathrm{c}, \mathrm{e}}$ & $12.50 \pm 0.49$ & $45.65 \pm 1.34^{x}$ \\
\hline B10/90 & $7.50 \pm 0.50^{\mathrm{d}}$ & $13.08 \pm 0.46^{\mathrm{c}, \mathrm{d}, \mathrm{e}}$ & $50.37 \pm 2.43^{\mathrm{x}}$ \\
\hline $\mathrm{S} 50 / 50$ & $7.31 \pm 0.14^{\mathrm{c}}$ & $13.33 \pm 0.23$ & $48.33 \pm 0.24^{\mathrm{g}}$ \\
\hline $\mathrm{S} 30 / 70$ & $7.16 \pm 0.18$ & $13.53 \pm 0.12$ & $48.87 \pm 1.51$ \\
\hline $\mathrm{S} 10 / 90$ & $6.86 \pm 0.35$ & $13.90 \pm 0.21$ & $47.28 \pm 0.55^{\mathrm{x}}$ \\
\hline
\end{tabular}


Table 7: Red blood cell absolute values in the different experimental groups.

\begin{tabular}{lllllc}
\hline Groups & $\begin{array}{c}\text { MCV } \\
\text { (fL/cell) }\end{array}$ & $\begin{array}{c}\text { MCH } \\
(\mathbf{p g} / \mathbf{c e l l})\end{array}$ & $\begin{array}{l}\text { MCHC } \\
(\mathbf{g} / \mathbf{d L})\end{array}$ & $\begin{array}{l}\text { RDW-SD } \\
(\mathbf{f L / c e l l})\end{array}$ & $\begin{array}{c}\text { RDW-CV } \\
(\%)\end{array}$ \\
\hline Control & $64.94 \pm 0.36$ & $18.70 \pm 0.18$ & $28.55 \pm 0.40$ & $41.82 \pm 0.27$ & $16.58 \pm 0.12$ \\
$\mathrm{SB} 50 / 50$ & $67.50 \pm 0.61$ & $19.35 \pm 0.14^{\mathrm{c}, \mathrm{x}}$ & $28.63 \pm 0.24$ & $44.02 \pm 0.19^{\mathrm{e}, \mathrm{g}}$ & $14.25 \pm 0.96^{\mathrm{c}}$ \\
$\mathrm{SB} 30 / 70$ & $66.62 \pm 1.51^{\mathrm{e}}$ & $18.88 \pm 0.22^{\mathrm{f}, \mathrm{y}}$ & $29.02 \pm 0.62^{\mathrm{f}, \mathrm{g}}$ & $43.49 \pm 4.78^{\mathrm{e}, \mathrm{g}}$ & $16.85 \pm 1.63^{\mathrm{d}, \mathrm{e}, \mathrm{h}}$ \\
$\mathrm{SB} 10 / 90$ & $66.63 \pm 1.40^{\mathrm{e}}$ & $18.68 \pm 0.14^{\mathrm{f}}$ & $28.07 \pm 0.57^{\mathrm{h}}$ & $45.10 \pm 2.73^{\mathrm{e}}$ & $18.40 \pm 1.12^{\mathrm{c}, \mathrm{e}, \mathrm{h}}$ \\
$\mathrm{B} 50 / 50$ & $72.20 \pm 0.74^{\mathrm{a}, \mathrm{c}}$ & $19.47 \pm 0.16^{\mathrm{b}}$ & $27.00 \pm 0.29^{\mathrm{c}, \mathrm{d}}$ & $63.68 \pm 2.65^{\mathrm{a}}$ & $24.10 \pm 1.28^{\mathrm{a}, \mathrm{c}}$ \\
$\mathrm{B} 30 / 70$ & $65.67 \pm 0.83^{\mathrm{e}}$ & $18.88 \pm 0.27^{\mathrm{y}}$ & $27.73 \pm 0.91$ & $42.55 \pm 1.05^{\mathrm{e}, \mathrm{g}}$ & $17.08 \pm 0.40^{\mathrm{e}}$ \\
$\mathrm{B} 10 / 90$ & $70.55 \pm 0.76^{\mathrm{a}, \mathrm{d}}$ & $18.38 \pm 0.27^{\mathrm{d}, \mathrm{e}, \mathrm{y}}$ & $26.50 \pm 0.64^{\mathrm{b}, \mathrm{d}}$ & $50.52 \pm 1.76^{\mathrm{a}, \mathrm{e}}$ & $21.37 \pm 0.35^{\mathrm{a}, \mathrm{c}}$ \\
$\mathrm{S} 50 / 50$ & $64.63 \pm 0.46^{\mathrm{d}, \mathrm{e}}$ & $18.40 \pm 0.16^{\mathrm{d}, \mathrm{e}, \mathrm{y}}$ & $28.32 \pm 0.17^{\mathrm{g}}$ & $37.65 \pm 0.30^{\mathrm{e}}$ & $14.90 \pm 0.22$ \\
$\mathrm{~S} 30 / 70$ & $66.97 \pm 1.86^{\mathrm{e}}$ & $19.07 \pm 0.23^{\mathrm{g}, \mathrm{y}}$ & $28.10 \pm 0.73^{\mathrm{g}}$ & $46.68 \pm 4.44^{\mathrm{e}}$ & $11.62 \pm 1.11^{\mathrm{a}, \mathrm{d}}$ \\
$\mathrm{S} 10 / 90$ & $68.87 \pm 0.70^{\mathrm{b}, \mathrm{f}}$ & $19.97 \pm 0.28^{\mathrm{a}}$ & $28.62 \pm 0.34^{\mathrm{f}, \mathrm{g}}$ & $41.93 \pm 0.53^{\mathrm{e}, \mathrm{g}}$ & $14.70 \pm 0.14$ \\
\hline
\end{tabular}

Values are mean \pm SEM, $n=6 ; a=p<0.001, b=p<0.01$ vs Control; $c=p<0.001, d=p<0.05$ vs SB50/50; $=p<0.001$ vs $\mathrm{B} 50 / 50 \& \mathrm{~B} 10 / 90 ; \mathrm{f}=\mathrm{p}<0.05$ vs $\mathrm{B} 50 / 50 ; \mathrm{g}=\mathrm{p}<0.05$ vs B10/90 \& B30/70; $\mathrm{h}=\mathrm{p}<0.001$ vs $\mathrm{S} 30 / 70 ; \mathrm{x}=\mathrm{p}<0.05$ vs $\mathrm{SB} 10 / 90 \&$ $\mathrm{S} 10 / 90 ; \mathrm{y}=\mathrm{p}<0.001$ vs $\mathrm{S} 10 / 90$.

$\mathrm{MCV}=$ mean corpuscular volume, $\mathrm{MCH}=$ mean corpuscular hemoglobin, $\mathrm{MCHC}=$ mean corpuscular hemoglobin concentration, RDW-SD = red blood cell distribution width (standard deviation), $\mathrm{RDW}-\mathrm{CV}=$ red blood cell distribution width (cell volume).

Table 8: Platelet indices in the different experimental groups.

\begin{tabular}{|c|c|c|c|c|}
\hline Groups & $\begin{array}{c}\text { PLT } \\
\left(\times 10^{3} \text { cell } / \mu L\right)\end{array}$ & $\begin{array}{l}\text { PDW } \\
\text { (fL) }\end{array}$ & $\begin{array}{l}\text { MPV } \\
\text { (fL) }\end{array}$ & $\begin{array}{l}\text { P-LCR } \\
(\%)\end{array}$ \\
\hline Control & $829.67 \pm 22.86$ & $10.97 \pm 0.27$ & $8.62 \pm 0.07$ & $8 \pm 0.81$ \\
\hline SB50/50 & $7.56 \pm 0.24^{\mathrm{a}}$ & $10.23 \pm 0.24^{\mathrm{h}}$ & $8.27 \pm 0.16$ & $16.53 \pm 0.17$ \\
\hline SB30/70 & $825.45 \pm 88.07^{y}$ & $10.12 \pm 0.52^{\mathrm{h}}$ & $8.40 \pm 0.15^{\mathrm{h}}$ & $15.07 \pm 0.65$ \\
\hline SB10/90 & $793.00 \pm 68.18^{\mathrm{f}, \mathrm{y}}$ & $10.77 \pm 0.50^{\mathrm{h}}$ & $8.31 \pm 0.20^{\mathrm{h}}$ & $14.38 \pm 1.55$ \\
\hline $\mathrm{B} 50 / 50$ & $475.33 \pm 32.45^{\mathrm{a}, \mathrm{e}, \mathrm{y}}$ & $11.22 \pm 0.28^{\mathrm{h}}$ & $8.67 \pm 0.26^{\mathrm{h}}$ & $17.55 \pm 1.46^{\mathrm{g}}$ \\
\hline B30/70 & $862.67 \pm 17.67^{\mathrm{y}, \mathrm{z}}$ & $8.98 \pm 0.27$ & $8.17 \pm 0.25^{\mathrm{h}}$ & $11.13 \pm 0.60^{\mathrm{c}, \mathrm{d}}$ \\
\hline B10/90 & $744.67 \pm 17.80^{\mathrm{r}, \mathrm{y}}$ & $6.93 \pm 2.51^{\mathrm{a}}$ & $5.73 \pm 2.00^{\mathrm{a}, \mathrm{d}}$ & $14.00 \pm 4.86$ \\
\hline $\mathrm{S} 50 / 50$ & $785.33 \pm 5.12^{\mathrm{r}, \mathrm{y}}$ & $10.90 \pm 0.20^{\mathrm{h}}$ & $8.33 \pm 0.09^{\mathrm{h}}$ & $15.13 \pm 0.42$ \\
\hline $\mathrm{S} 30 / 70$ & $590.00 \pm 13.92^{c, g, y}$ & $10.88 \pm 0.58^{\mathrm{h}}$ & $7.93 \pm 0.21^{\mathrm{h}}$ & $13.70 \pm 0.96$ \\
\hline $\mathrm{S} 10 / 90$ & $818.83 \pm 43.74^{\mathrm{e}, \mathrm{y}}$ & $10.38 \pm 0.26^{\mathrm{h}}$ & $8.27 \pm 0.12^{\mathrm{h}}$ & $13.62 \pm 0.93$ \\
\hline
\end{tabular}

Values are mean \pm SEM, $\mathrm{n}=6$; $\mathrm{a}=\mathrm{p}<0.001, \mathrm{c}=\mathrm{p}<0.01$ vs Control; $\mathrm{y}=\mathrm{p}<0.001, \mathrm{~d}=\mathrm{p}<0.05$ vs SB50/50; $=\mathrm{p}<0.00$; $\mathrm{f}=\mathrm{p}<0.05, \mathrm{~g}=\mathrm{p}<0.01$ vs B30/70; $\mathrm{r}=\mathrm{p}<0.05$ vs B50/50; $\mathrm{h}=\mathrm{p}<0.01$ vs $\mathrm{B} 10 / 90 ; \mathrm{x}=\mathrm{p}<0.001, \mathrm{z}=\mathrm{p}<0.01$ vs SB10/90. $\mathrm{PLT}=$ platelet, $\mathrm{PDW}=$ platelet distribution width, $\mathrm{MPV}=$ mean platelet volume; $\mathrm{P}-\mathrm{LCR}=$ platelet layer cell ratio. 


\section{DISCUSSION}

Due to their role in the defense of an organism against attack, increasing the number of lymphocytes through diet will result in boosting the immune system as seen in this study. The increased concentration of WBCs in almost all the test groups implies that jackfruit is capable of boosting the immune system, thus supporting the antibacterial, antifungal, antiviral and immunostimulative properties of jackfruit earlier reported by Morton (1987).

Eosinophils are a type of white blood cells that play an important role in the immune system particularly in the body's response to allergic reactions, asthma and in fighting parasitic infections (Territo, 2016; Mori et al, 2009). Mori et al. (2009) also reported that the normal range for blood eosinophils is $40-400$ cells $/ \mu \mathrm{L}$ in humans and $15-250$ cells $/ \mu \mathrm{L}$ in rats and so the term eosinophilia refers to conditions where abnormally high number of eosinophils is found either in the blood $(600-1500$ cells $/ \mu \mathrm{L})$ or tissues. Less than $7 \%$ of the circulating leukocytes are usually accounted for by the eosinophils (Territo, 2016). As stated earlier, one of the causes of eosinophilia is allergic reaction, although, it is not a disorder except it is idiopathic (Beers et al, 2006). In this study, the eosinophil count of the groups fed diets supplemented with bulb at both $10 \%, 30 \%$ and $50 \%$ exceeded the normal ranges reported by Mori et al. (2009) for both humans (0.49 $\mathrm{x} 10^{3}$ cell $/ \mu \mathrm{L}$ in group $\left.\mathrm{B} 50 / 50\right)$ and rats indicating that there was, probably, an allergic reaction. It may, therefore, be advisable that caution should be taken when eating jackfruit bulb since over consumption could result in allergy. This is in line with the report of Kristie (Kristie, 2011) that those who are suffering from birch pollen syndrome should avoid consuming this fruit.

There is a direct relationship among the hematological indices. For example, increase in RBC count may lead to the corresponding increase in $\mathrm{Hb}$ and Hematocrit
(HCT) (Pedersen and Milman, 2003). The direct erythrocyte indices, $\mathrm{MCV}, \mathrm{MCH}$ and $\mathrm{MCHC}$, measure the size, weight per unit volume of red blood cells. The size of the cells may be normal (normocytic), below normal (microcytic) and above (macrocytic). This is similar to what is obtainable in iron deficiency aneamia (Pedersen and Milman, 2003). These researchers reported that $\mathrm{MCH}$ is decreased in hypochromatic and elevated in macrocytic aneamia. The present study showed significant increases in MCV and $\mathrm{MCH}$ in groups fed $\mathrm{B} 50 / 50$ and $\mathrm{S} 10 / 90$ diets signifying a macrocytic anaemic condition.

Platelet count is one of the most important screen tests of platelet function. A decrease in the circulating platelets less than $50 \%$ of the normal value will cause bleeding (Beers et al, 2006). The decreases observed in the platelet counts in groups S30/70, B50/50 and SB50/50 may indicate possible effects on blood clotting when jackfruit diets are consumed at these levels of supplementation.

Though daily food intake was significantly higher in group B50/50, there was an observed decrease in body weight. This could be attributed to the presence of some anti-nutritional factors such as oxalate and phytate which could make the nutrients in the diet bio-unavailable to the rats. Investigation in this area is necessary. The low body weight observed in this group as well as groups $\mathrm{S} 50 / 50$ and $\mathrm{B} 30 / 70$ may have been responsible for the reduced $\mathrm{WBC}, \mathrm{RBC}$ and PCV (except group S50/50) values recorded in these groups compared to other experimental groups.

\section{Conclusion}

It may be concluded from the findings in this study that jackfruit diets possess some anti-anaemic properties as it was seen in the improved $\mathrm{RBC}, \mathrm{Hb}$, and PCV values obtained for $10 \%$ supplementation with jackfruit bulb (B10/90) or seed-bulb blend (SB10/90). The fruit is capable of enhancing the immune system, the platelet counts were decreased in 
some groups, indicating possible effects on blood clotting when jackfruit diets are consumed at such levels of supplementation. However, excess consumption of jackfruit bulb may cause an allergic effect.

\section{COMPETING INTERESTS}

We state that there are no competing interests either financially or otherwise that might be perceived as influencing any of the authors' objectivity.

\section{AUTHORS' CONTRIBUTIONS}

MAA designed the study, generated the initial manuscript and supervised the work; BSD carried out the study, did the statistical analysis, and produced the final manuscript; IOW and ABU supplied the relevant literature materials and participated in reading and approving the final manuscript.

\section{ACKNOWLEDGEMENTS}

We are grateful to the Department of Biochemistry, University of Calabar for providing the space for the animal study. We also appreciate Mr. Kelvin Elot, Dr. E. Modo, Dr. IA Iwara, and Mr. M. Ategwu for their assistance in the handling of the experimental animals and in the laboratory analysis; Prof. F. Uboh and Associate Prof. E. David-Oku for the professional guidance. Finaly, we thank the families of Asegame Daicy and Mr. Joel Eugene for their financial assistance.

\section{REFERENCES}

Agboola OS. 2014. Antioxidant potentials of local fruits and foreign wines sold in IleIfe, Nigeria. Int. J. Biol. Chem. Sci., 8(2): 699-704. DOI: $10.4314 /$ ijbcs.v8i2.26

Albokhadaim I. 2015. Influence of dietary supplementation of propolis on hematology, biochemistry and lipid profile of rats fed high cholesterol diet. $J$. Adv. Vet. Anim. Res., 2(1): 56-63. DOI: $10.5455 /$ javar.2015.b49

Asif M. 2014. The prevention and control the type-2 diabetes by changing lifestyle and dietary pattern. J. Educ. Health Promot., 3: 1-14. DOI: $10.4103 / 2277-$ 9531.127541

Balogun ME, Folawiyo MA, Besong EE, Jeje SO. 2014. Effect of ethanolic fruit extract of Adenopus breviflorus (Lagenaria breviflora Robert) on hematological indices in male Albino Wistar rats. J. Phys. Pharm. Adv., 4(11): 501-508.

DOI: $10.5455 /$ jppa.20141117043323

Beers M, Porter R, Jones T. 2006. The Merck Manual of Diagnosis and Therapy $\left(18^{\text {th }}\right.$ edn). Merck Research Laboratories: Whitehouse Station, New Jersey.

Celik A, Ozcan IT, Ahmet Gündes A, Topuz M, Pektas I, Yesil E, Ayhan S, Kose A, Camsari A, Cin VG. 2015. Usefulness of admission of hematologic parameters as diagnostic tools in acute pulmonary embolism. Kaohsiung J. Med. Sci., 31: 145-149.

DOI: 10.1016/j.kjms.2014.12.004.

Deepak K. 2012. Jackfruit Health Benefits and Nutrition Facts. www.fitnessworld.com/jackfruit, Retrieved 9 April, 2013.

Dike MC, Nnamdi EA. 2012. Comparative study of proximate, phytochemical and mineral compositions of edible plant fruits/seeds from Nigerian rainforest. Int. J. Biol. Chem. Sci., 6(4): 1905-1909. DOI: $10.4314 /$ ijbcs.v6i4.43

Donaldson MS. 2004. Nutrition and cancer: A review of the evidence for an anti-cancer diet. Nutr. J., 3: 19-40. DOI: $10.1186 / 1475-2891-3-19$

Donfack VFD, Roque S, Trigo G, Fokou P, Tchokouaha LRY, Tsabang N, Zollo PHA, Correia-Neves M, Boyom FF. 2014. Antimycobacterial activity of selected medicinal plants extracts from Cameroon. Int. J. Biol. Chem. Sci., 8(1): 273-288. DOI: 10.4314/ijbcs.v8i1.24

Erasto P, Tshikalange TE. 2010. Antioxidant and HPTLC profile of the leaf and fruit extracts of Lagenaria siceraria. Int. J. 
Biol. Chem. Sci., 4(6): 2379-2386. http://ajol.info/index.php/ijbcs.

Erukainure OL, Ebuehi OAT, Adeboyejo FO, Aliyu M, Elemo GN. 2013. Hematological and biochemical changes in diabetic rats fed with fiber-enriched cake, J. Acute Med. 3(1): 1-6. http://dx.doi.org/10.1016/j.jacme.2013.0 3.001

Etim NN, Enyenihi GE, Akpabio U, Offiong EEA. 2014. Effects of nutrition on haematology of rabbits: A Review. ESJ, 10(3):413-424.

http://eujournal.org/index.php/esj/article/ viewFile/2638/2499.

European Treaty Series No 1232005. European Convection for the Protection of vertebrate animals used for the experimental and other scientific purposes, article $5 \mathrm{p}$ 46. Strasbourg, 18.III.1986. Retrieved from

https://rm.coe.int/CoERMPublicCommo nSearchServices/DisplayDCTMContent? documentId $=090000168007 \mathrm{a} 67 \mathrm{~b}$.

Fernández AC, Pintor de la Maza B, Casariego AV, Taibo RV, Gómez JJL, Rodríguez IC, Pomar MDB. 2015. Food intake and nutritional status influence outcomes in hospitalized hematologyoncology patients. Nutr. Hosp., 31(6): 2598-2605.

DOI:10.3305/nh.2015.31.6.8674.

Haddad EH, Berk LS, Kettering JD, Hubbard RW, Peters WR. 1999. Dietary intake and biochemical, hematologic, and immune status of vegans compared with nonvegetarians. Am J. Clin. Nutr., 70 (suppl): $\quad$ 586S-593S.

https://www.ncbi.nlm.nih.gov/pubmed/1 0479236.

Kadir MF, Bin Sayeed MS, Setu NI, Mostafa A, Mia MM. 2014. Ethnopharmacological survey of medicinal plants used by traditional health practitioners in Thanchi, Bandarban Hill Tracts, Bangladesh. $J$.
Ethnopharmacol., $\quad \mathbf{1 5 5}(1): \quad 495-508$. DOI: 10.1016/j.jep2014.05.043.

Kevat D. 2013. Jackfruit 10 health benefits and nutrition facts|Jackfruit, Retrieved from www.wiki-fitness.com on $2^{\text {nd }}$ June, 2016.

Kristie K. 2011. 10 Health Benefits of Jackfruit, Retrieved 3 June, 2016 from www.healthwikinut.com

Lavy A, Fuhrman B, Markel A, Dankner G, Ben-Amotz A, Presser D, Aviram M. 1994. Effect of dietary supplementation of red or white wine on human blood chemistry, hematology and coagulation: favorable effect of red wine on plasma high-density lipoprotein. Ann. Nut. Metab., 38(5): 287-294. https://www.ncbi.nlm.nih.gov/pubmed/7 535990.

Mori M, Li G, Hashimoto M, Nishio A, Tomozawa H, Suzuki N, Usami S, Higuchi K, Matsumoto K. 2009. Pivotal advance: Eosinophilia in MES rat strain is caused by a loss-of-function mutation in the gene for cytochrome b(-245), alpha polypeptide (Cyba). J. Leukoc. Biol., $\quad$ 86: 473-478. https://www.ncbi.nlm.nih.gov/pubmed/1 9406829.

Morton J. 1987. Fruits of Warm Climates ( $1^{\text {st }}$ edn). Julia F. Morton: Miami, Florida.

Okafor OE, Ezeanyika LUS, Ujowundu CUO. 2015. Effect of traditional processing techniques on the proximate and mineral compositions of jackfruit (Artocarpus heterophyllus) seeds. Int'l Conference on Food Nutrition, Chemical and Environmental Engg. (ICFNCE’2015) Aug. 25-26, Kuala Lumpur, Malaysia.

Okolo I, Owolabi OA, James DB, Sallau AB, Andongma BT, Moses CA. 2015. The haemoglobin regeneration potential of fermented and unfermented Telfaira occidentalis and Gnetum africanum leaves in iron deficient albino rats. Int. $J$. Biol. Chem. Sci. 9(4): 1742-1754. http://www.ajol.info 
Owoeye O, Onwuka SK, Farombi EO. 2011. Vernonia amygdalina leaf extract and alpha-tocopherol alleviated gamma radiation-induced haematological and biochemical changes in rats. Int. J. Biol. Chem. Sci., 5(5): 1978-1992. DOI: 10.4314/ijbcs.v5i5.18

Oyewole OI, Malamo SO, Arise RO. 2009. Haematological evaluation in rats following administration of some antisickling agents. Int. J. Biol. Chem. Sci., 3(2): 410-414. http://www.ajol.info

Pedersen P, Milman N. 2003. Diagnostic Significance of Platelet Count and other Blood Analyses in Patients with Lung Cancer. Oncol. Rep., 10(1): 213-216. https://www.ncbi.nlm.nih.gov/pubmed/1 2469171.

Ray PK. 2002. Breeding tropical and subtropical fruits. Springer-Verlag/ Narosa Publishing House, New Delhi, India.
Shi HL, Noguchi N, Niki E. 2001. Introducing natural antioxidants. In Antioxidants in Food: Practical Applications, Pokorny J, Yanishlieva N, Gordon M (eds). Woodhead Publishing Ltd; 147-155.

Syahida M, Maskat MY, Suri R, Mamot S, Hadijah H. 2012. Soursop (Anona muricata L.): Blood hematology and serum biochemistry of Sprague-Dawley rats. Int. Food Res. J. 19(3): 955-959. www.geyseco.es/geystiona/adjs/comunic aciones/304/C04590001.pdf.

Territo M. 2016. Eosinophilic disorders. Retrieved on 14 June, 2016 from www.merckmanuals.com

Williams IO, Edet EJ, Agiang MA, Lawal OO. 2009. Fruit and vegetable intake pattern and body mass index (BMI) of postgraduate students in the University of Calabar, Nigeria. Nig. J. Nutr. Sci., 30(2): $43-49$. 